\title{
Analisis Penggunaan dan Syarat Mutu Minyak Goreng pada Penjaja Makanan di Food Court UAI
}

\author{
Nita Noriko*, Dewi Elfidasari, Analekta Tiara Perdana, Ninditasya Wulandari, Widhi Wijayanti \\ Program Studi Biologi, Fakultas Sains dan Teknologi, \\ Universitas Al Azhar Indonesia, Jl. Sisingamangaraja, Jakarta 12110 \\ *Penulis untuk Korespondensi: nita_noriko@uai.ac.id
}

Abstrak - Masyarakat Indonesia memiliki ketergantungan terhadap minyak goreng. Berdasarkan hal tersebut, perlu dilakukan penelitian tentang penggunaan dan mutu minyak goreng yang beredar di masyarakat khususnya pada food court Universitas Al Azhar Indonesia. Analisis penggunaan minyak goreng penjaja makanan dilakukan dengan melakukan survey. Untuk mengetahui kualitas minyak goreng, dilakukan analisis laboratorium yang meliputi pengukuran kadar air, kadar asam lemak bebas, dan bilangan Iod. Dari dua belas kantin, ada sembilan kantin yang menggunakan minyak goreng. Hasil analisis penggunaan minyak goreng, penjaja makanan secara konsisten $34 \%$ menggunakan minyak goreng bermerek dagang A. Pemilihan minyak berdasarkan warna dilakukan oleh $45 \%$ penjaja makanan. Berdasarkan frekuensi pembelian, $56 \%$ penjaja makanan membeli minyak per hari. Selain itu, $45 \%$ penjaja makanan menggunakan minyak dua kali pakai. Analisis kebutuhan minyak menunjukkan, $34 \%$ penjaja makanan menghabiskan 5 liter minyak per hari. Cara pembuangan minyak yang dilakukan oleh penjaja, $78 \%$ membuang minyaknya setelah digunakan, dimana $67 \%$ penjaja makanan membuangnya ke tempat sampah. Berdasarkan pengukuran kadar air, kadar asam lemak bebas, dan bilangan Iod menunjukkan bahwa minyak goreng yang digunakan belum memenuhi standar syarat mutu, walaupun kadar air yang masih di dalam ambang batas normal yaitu kurang dari $0,30 \%$, namun kadar asam lemak bebas baik sebelum maupun sesudah penggunaan melebihi ambang batas normal yang didukung oleh hasil pengukuran bilangan Iod.
Abstract - Indonesian society has dependence of cooking oil. Based on this condition, the analysis of cooking oil utilization and quality requirement at UAI food court is necessary and it was done. The analysis of cooking oil utilization was done by doing some survey. In order to search the quality of cooking oil, laboratory analysis was done that consist of water content, free fatty acid content, and Iod number. There are nine canteens from twelve canteens which utilize cooking oil. The result of cooking oil utilization analysis shows that $34 \%$ of merchant is utilizing $A$ trade mark cooking oil, $45 \%$ is identifying cooking oil based on color. $56 \%$ is buying cooking oil per day, $45 \%$ is utilizing the cooking oil twice, $34 \%$ is spending 5 liters cooking oil per day, $\mathbf{7 8 \%}$ is casting the cooking oil after utilize it, and $67 \%$ is casting the cooking oil into trash can. Based on the result of water content, free fatty acid content, and Iod number analysis showed that cooking oil is never fulfill normal limit, although the water content is still in proper limit is less than $0,30 \%$, whereas free fatty acid content before or after analysis are very high and do not in proper limit and it is supported by Iod number measurement result.

Keywords - cooking oil, utilization analysis, quality requirement analysis.

\section{PENDAHULUAN}

$\mathrm{P}$ enggunaan minyak goreng untuk mengolah makanan, umumnya dilakukan oleh masyarakat. Hal ini disebabkan adanya anggapan masyarakat awam bahwa makanan yang digoreng akan terasa lebih gurih dan nikmat [1]. Setiap produsen minyak goreng mempromosikan bahwa produknya adalah produk yang terbaik dan 
menyehatkan, misalnya mengandung omega 3 dan 9, vitamin $\mathrm{A}, \mathrm{D}$ dan $\mathrm{E}$, melalui dua kali penyaringan dan tidak mengandung kolesterol.

Menurut [2] minyak goreng adalah minyak yang berasal dari lemak tumbuhan atau hewan yang dimurnikan dan berbentuk cair dalam suhu kamar dan biasanya digunakan untuk menggoreng makanan. Di Indonesia, minyak goreng diproduksi dari minyak kelapa sawit dalam skala besar. Hingga tahun 2010 diperkirakan produksi minyak sawit mencapai lebih dari 3 juta ton per tahun [1]. Memperhatikan peningkatan produksi minyak goreng dan tingginya tingkat ketergantungan masyarakat terhadap minyak goreng, maka dipandang perlu dilakukan analisis penggunaan dan syarat mutu minyak goreng yang digunakan oleh masyarakat terutama penjaja makanan di food court Universitas Al Azhar Indonesia.

Penelitian ini dilakukan untuk menguji penggunaan minyak goreng dan pemenuhan syarat mutu minyak goreng pada penjaja makanan di food court UAI melalui analisis penggunaan dan syarat mutu minyak goreng. Analisis penggunaan minyak goreng dilakukan dengan mensurvey kantin di food court UAI yang menggunakan minyak goreng untuk membuat menu dagangannya, sedangkan analisis syarat mutu minyak goreng dilakukan berdasarkan analisis kadar air, asam lemak bebas, dan bilangan iod.

\section{TINJAUAN PUSTAKA}

Minyak goreng adalah minyak yang dipakai untuk menggoreng, seperti minyak kelapa, minyak jagung, minyak kacang [3]. Minyak goreng tersusun atas asam lemak berbeda yaitu sekitar dua puluh jenis asam lemak. Setiap minyak atau lemak tidak ada yang hanya tersusun atas satu jenis asam lemak, karena minyak atau lemak selalu ada dalam bentuk campuran dari berberapa asam lemak. Asam lemak yang dikandung oleh minyak sangat menentukan mutu dari minyak, karena asam lemak tersebut menentukan sifat kimia dan stabilitas minyak [4]. Berikut ini disajikan jenis-jenis asam lemak yang terdapat pada minyak nabati yang dapat digunakan untuk menggoreng (Tabel 1).
Tabel 1. Komposisi Beberapa Asam Lemak dalam Tiga Minyak Nabati

\begin{tabular}{|c|c|c|c|c|}
\hline $\begin{array}{c}\text { Asam } \\
\text { Lemak }\end{array}$ & $\begin{array}{c}\text { Jumlah } \\
\text { Atom } \\
\text { C }\end{array}$ & $\begin{array}{c}\text { Minyak } \\
\text { Sawit } \\
(\%)\end{array}$ & $\begin{array}{l}\text { Minyak } \\
\text { Inti }(\%)\end{array}$ & $\begin{array}{c}\text { Minyak } \\
\text { Kelapa } \\
(\%)\end{array}$ \\
\hline \multicolumn{5}{|c|}{ Asam Lemak Jenuh: } \\
\hline Oktanoat & 8 & - & $2-4$ & 8 \\
\hline Dekanoat & 10 & - & $3-7$ & 7 \\
\hline Laurat & 12 & 1 & $41-55$ & 48 \\
\hline Miristat & 14 & $1-2$ & $14-19$ & 17 \\
\hline Palmitat & 16 & $32-47$ & $6-10$ & 9 \\
\hline Stearat & 18 & $4-10$ & $1-4$ & 2 \\
\hline \multicolumn{5}{|c|}{ Asam Lemak Tidak Jenuh: } \\
\hline Oleat & 18 & $38-50$ & $10-20$ & 6 \\
\hline Linoleat & 18 & $5-14$ & $1-5$ & 3 \\
\hline Linolenat & 18 & 1 & $1-5$ & - \\
\hline
\end{tabular}

Sumber: Majalah Sasaran No.4, 1996 [5]

Kerusakan minyak akan mempengaruhi kualitas dan nilai gizi makanan yang digoreng. Pemanasan minyak goreng dengan suhu yang sangat tinggi akan menyebabkan sebagian minyak teroksidasi. Minyak yang rusak akibat proses oksidasi akan menghasilkan makanan berwarna kurang menarik dan rasa yang tidak enak, serta kerusakan beberapa vitamin dan asam lemak esensial di dalam minyak. Proses oksidasi tersebut terjadi saat minyak tersebut mengalami kontak dengan sejumlah oksigen. Reaksi oksidasi juga akan menimbulkan bau tengik pada minyak dan lemak [6]. Selain menimbulkan bau tengik, radikal bebas juga dapat terbentuk akibat oksidasi yang mempunyai dampak merusak sel dan jaringan tubuh. Hal ini disebabkan radikal bebas bersifat sangat reaktif [7].

Syarat mutu minyak goreng yang dipakai oleh masyarakat, harus berdasarkan Departemen Perindustrian seperti yang disajikan pada Tabel 2. Hal ini disebabkan, minyak goreng yang digunakan dapat menimbulkan dampak negatif bagi kesehatan [8]. 
Tabel 2. Syarat Mutu Minyak Goreng

\begin{tabular}{|c|c|c|}
\hline Kriteria Uji & Satuan & Syarat \\
\hline $\begin{array}{l}\text { Keadaaan bau, warna } \\
\text { dan rasa }\end{array}$ & - & Normal \\
\hline Air & $\% \mathrm{~b} / \mathrm{b}$ & Maks 0,30 \\
\hline $\begin{array}{l}\text { Asam lemak bebas } \\
\text { (dihitung sebagai } \\
\text { asam laurat) }\end{array}$ & $\% \mathrm{~b} / \mathrm{b}$ & Maks 0,30 \\
\hline $\begin{array}{l}\text { Bahan makanan } \\
\text { tambahan }\end{array}$ & \multicolumn{2}{|c|}{$\begin{array}{c}\text { Sesuai SNI. 022-M dan Permenkes } \\
\text { No. } 722 / \text { Menkes/Per/IX/88 }\end{array}$} \\
\hline $\begin{array}{cl}\text { Cemaran Logam: } \\
\text { - } & \text { Besi }(\mathrm{Fe}) \\
\text { - } & \text { Tembaga }(\mathrm{Cu}) \\
\text { - } & \text { Raksa }(\mathrm{Hg}) \\
\text { - } & \text { Timbal }(\mathrm{Pb}) \\
- & \text { Timah }(\mathrm{Sn}) \\
- & \text { Seng }(\mathrm{Zn})\end{array}$ & $\begin{array}{l}\mathrm{Mg} / \mathrm{kg} \\
\mathrm{Mg} / \mathrm{kg} \\
\mathrm{Mg} / \mathrm{kg} \\
\mathrm{Mg} / \mathrm{kg} \\
\mathrm{Mg} / \mathrm{kg} \\
\mathrm{Mg} / \mathrm{kg}\end{array}$ & $\begin{array}{c}\text { Maks 1,5 } \\
\text { Maks 0,1 } \\
\text { Maks 0,1 } \\
\text { Maks 40,0 } \\
\text { Maks 0,005 } \\
\text { Maks 40,0/250,0) }\end{array}$ \\
\hline $\begin{array}{l}\text { Arsen (As) } \\
\text { Angka Peroksida }\end{array}$ & $\begin{array}{c}\% \mathrm{~b} / \mathrm{b} \\
\% \mathrm{mg} \mathrm{02/g}\end{array}$ & $\begin{array}{l}\text { Maks } 0,1 \\
\text { Maks } 1\end{array}$ \\
\hline
\end{tabular}

Sumber: Departeman Perindustrian (SNI 01-3741-1995) [9]

*) Dalam kemasan kaleng

\section{METODE PENELITIAN}

\subsection{Waktu dan Tempat Penelitian}

Survey dilakukan pada 9 kantin di food court UAI yang menggunakan minyak goreng. Analisis syarat mutu minyak goreng dilakukan di laboratorium kimia Universitas Al Azhar Indonesia dan Laboratorium Terpadu, Universitas Syarif Hidayatullah Jakarta, JL.Ir.H. Juanda No.95 Ciputat. Waktu penelitian dimulai dari April 2011 s.d Oktober 2011.

\subsection{Prosedur Penelitian}

Analisis penggunaan minyak goreng penjaja makanan di food court UAI dilakukan dengan mensurvey kantin di food court UAI yang menggunakan minyak goreng untuk membuat menu dagangannya. Dari dua belas kantin, ada sembilan kantin yang menggunakan minyak goreng. Parameter yang digunakan adalah merek minyak goreng, cara pemilihan, frekuensi pembelian, frekuensi penggunaan, volume kebutuhan dan tempat pembuangan

Analisis syarat mutu minyak goreng penjaja makanan di food court UAI dilakukan dengan mengambil sampel minyak goreng dari tiga kantin yang berdasarkan survey menggunakan minyak goreng lebih dari satu kali. Analisis ini dilakukan berdasarkan analisis kadar air, asam lemak bebas dan bilangan iod.

Analisis kadar air dilakukan dengan mengeringkan sampel minyak goreng di dalam oven $100^{\circ} \mathrm{C}-102^{\circ} \mathrm{C}$ sampai diperoleh berat yang tetap. Cara kerja analisis kadar air, asam lemak bebas dan bilangan Iod diperoleh dari [10] pada SNI 01-3555-1998. Cawan kosong dan tutupnya dikeringkan dalam oven selama 15 menit dan didinginkan dalam desikator, kemudian ditimbang. Selanjutnya 5 gr sampel minyak goreng yang sudah dihomogenkan dalam cawan ditimbang. Kemudian, tutup cawan diangkat dan cawan berisi sampel minyak goreng dalam kondisi terbuka dan tutupnya juga ikut ditempatkan di dalam oven $60^{\circ}$ Celcius selama enam jam. Kontak antara cawan dengan dinding oven dihindarkan. Setelah itu, cawan dipindahkan ke desikator, lalu ditutup dengan penutup cawan dan didinginkan. Untuk selanjutnya ditimbang kembali. Proses pemanasan ini dapat dilakukan berkali-kali hingga memperoleh berat yang konstan. Kemudian dilakukan perhitungan persen kadar air dengan rumus sebagai berikut:

$$
\% \text { Kadar air }=\frac{X_{1}-X_{2}}{X_{1}} \times 100 \%
$$

Keterangan:

$\mathrm{X}_{1}=$ Berat Awal Minyak

$\mathrm{X}_{2}=$ Berat Akhir Minyak

Analisis kadar asam lemak bebas (free fatty acid) ditentukan sebagai kandungan asam lemak yang terdapat paling banyak dalam minyak tertentu. Asam lemak terbanyak yang dimiliki oleh sawit adalah asam palmitat [11]. Cara kerja analisis kadar asam lemak bebas adalah dengan mengaduk minyak dalam keadaan cair, setelah itu ditimbang sebanyak 28,2 $\pm 0,2$ gr dalam Erlenmeyer. Kemudian, $50 \mathrm{~mL}$ Alkohol netral $96 \%$ yang telah dipanaskan sampai mendidih dan $2 \mathrm{~mL}$ indikator fenolphtalein (PP) ditambahkan. Kemudian dititrasi dengan larutan $0,1 \quad \mathrm{~N} \quad \mathrm{NaOH}$ yang telah distandardisasi sampai berubah menjadi warna merah jambu dan tidak hilang selama 30 detik. Asam lemak bebas dinyatakan sebagai \% FFA (free fatty acid) atau sebagai angka asam. Angka asam merupakan mg $\mathrm{KOH}$ yang dibutuhkan untuk meneralkan 1 gr minyak.

Bilangan Iod dilakukan dengan metode Wijs. Metode in menggunakan beberapa pereaksi yaitu kloroform atau karbon tetraklorida, larutan sodium 
tiosulfat $0,1 \mathrm{~N}$ standar, larutan $\mathrm{KI} 15 \%$, larutan indikator pati, dan pereaksi Wijs. Penetapan bilangan Iod adalah dengan menimbang 0,1-0,5 gr sampel minyak. Kemudian, $15 \mathrm{~mL}$ kloroform atau karbon tetraklorinasi ditambahkan untuk melarutkan sampel minyak. Kemudian pereaksi Wijs $25 \mathrm{~mL}$ ditambahkan dan ditempatkan dalam ruangan gelap selama 30 menit sambil dikocok. Sesudah 30 menit, $20 \mathrm{~mL}$ larutan KI $15 \%$ ditambahkan dan kemudian dikocok merata. Erlenmeyer tempat pereaksi dan tutupnya dicuci dengan $100 \mathrm{~mL}$ akuades yang baru dan dingin, kemudian dimasukkan ke dalam larutan. Titrasi dilakukan dengan dengan $\mathrm{Na}_{2} \mathrm{~S}_{2} \mathrm{O}_{3} \quad 0,1 \mathrm{~N}$ yang disertai dengan pengocokan yang konstan. Sebagai indikator, digunakan Larutan pati $1 \%$. Selanjutnya, blanko dibuat seperti pada penetapan sampel dan sampel minyak diganti dengan kloroform/CCI. Setelah itu dilakukan perhitungan.

\section{HASIL DAN PEMBAHASAN}

\subsection{Hasil Analisis Penggunaan Minyak Goreng}

\subsubsection{Hasil Survey Penggunaan Merk Minyak Goreng}

Minyak goreng bermerek dagang A adalah merek minyak goreng yang paling banyak digunakan oleh penjaja makanan di food court UAI yaitu sebesar $34 \%$, diikuti oleh minyak goreng bermerek dagang B sebesar 22\% dan minyak goreng bermerek dagang $\mathrm{C}$ sebesar $11 \%$. Sedangkan $33 \%$ penjaja makanan lainnya terkadang memilih untuk mencampur merek minyak goreng satu dengan yang lain, adapula yang tidak tahu merek minyak goreng yang digunakan seperti pada Gambar 1 . Minyak goreng bermerek dagang A banyak dipilih oleh penjaja makanan karena warna minyak goreng tersebut kuning dan jernih.

\subsubsection{Hasil Survey Frekuensi Pembelian Minyak Goreng}

Berdasarkan frekuensi pembelian minyak goreng, 56\% dari penjaja makanan di food court UAI membeli minyak goreng per hari, diikuti frekuensi pembelian per mingu sebesar 33\%, kemudian terakhir $11 \%$ penjaja makanan membeli minyak goreng per bulan seperti pada Gambar 2. Penjaja makanan membeli minyak goreng per hari karena penjaja makanan belum dapat memprediksi penjualan makanan setiap harinya sehingga untuk menghindari kelebihan minyak goreng, pembelian dilakukan per hari.

\subsubsection{Hasil Sirvey Penggunaan Minyak Goreng} Berdasarkan frekuensi penggunaan minyak goreng tertinggi yaitu dua kali penggunaan sebesar $45 \%$, diikuti dengan satu kali penggunaan sebesar 33\%, dan $22 \%$ penjaja makanan lainnya menggunakan minyak goreng lebih dari dua kali seperti pada Gambar 3. Penjaja makanan menggunakan minyak goreng sebanyak dua kali karena penjaja makanan di foodcourt UAI tergolong menengah ke atas, sehingga para penjaja makanan mengetahui bahaya penggunaan minyak goreng berkali-kali

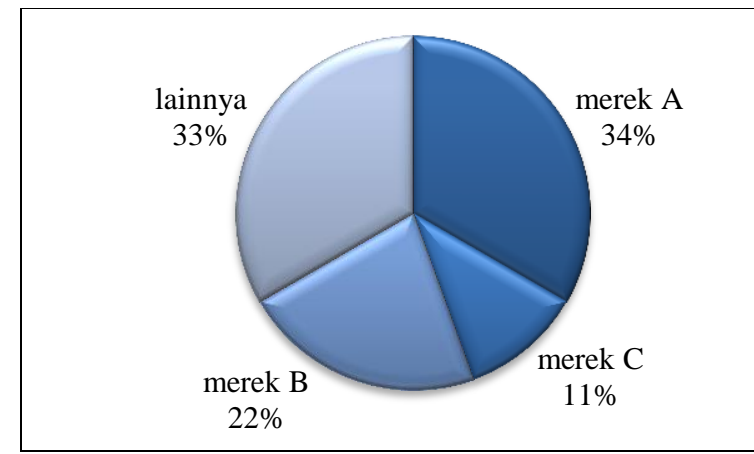

Gambar 1. Persentase Penggunaan Merk Minyak Goreng

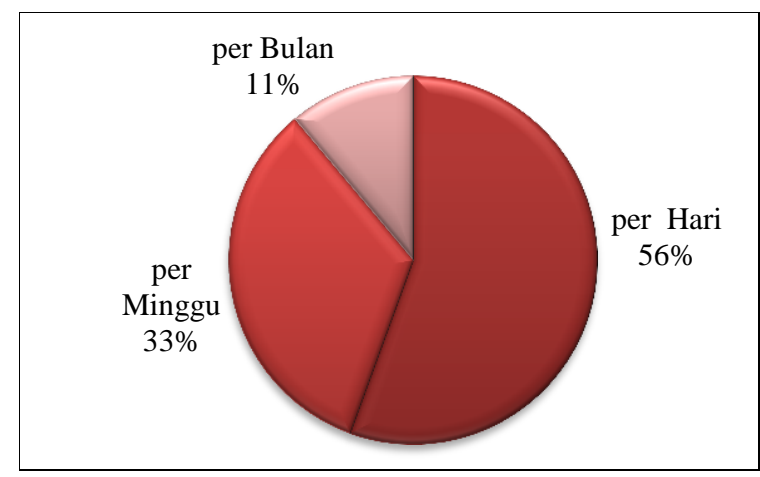

Gambar 2. Persentase Frekuensi Pembelian Minyak Goreng

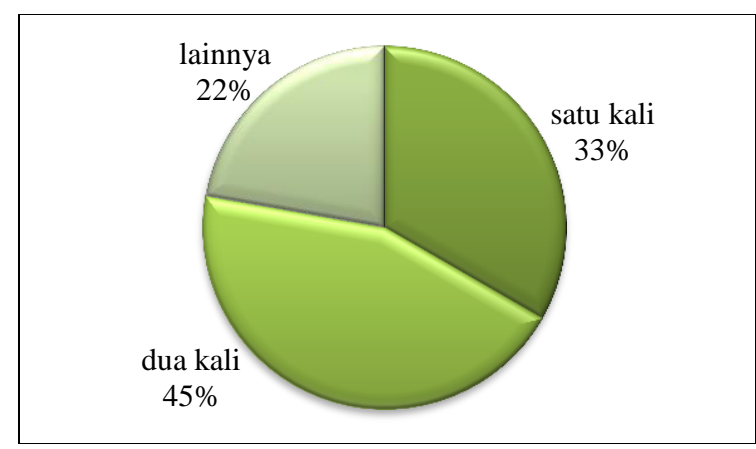

Gambar 3. Persentase Frekuensi Penggunaan Minyak Goreng 


\subsubsection{Hasil Survey Volume Penggunaan Minyak Goreng}

Berdasarkan volume penggunaan, volume penggunaan minyak goreng tertinggi per hari adalah 5 liter yaitu sebesar 34\%. Volume penggunaan minyak sebanyak 1 dan 2,5 liter sebesar $22 \%$ dan $11 \%$ untuk penggunaan volume 2 dan 3 liter seperti pada Gambar 4. Volume minyak goreng yang digunakan sebanyak $5 \mathrm{~L}$ dapat terjadi karena jumlah penjualan makanan yang diproses dengan menggoreng cukup banyak.

\subsubsection{Hasil Survey Perlakuan Minyak Goreng Setelah Digunakan}

Berdasarkan cara pembuangannya, sebesar $78 \%$ penjaja makanan di food court UAI memilih membuang minyak goreng habis pakai dan sisanya memilih menyimpan minyak habis pakai untuk dijual kembali seperti pada Gambar 5. Penjaja makanan memilih untuk membuang minyak goreng karena para penjaja makanan tidak menggunakan minyak berkali-kali sehingga minyak sisa menggoreng langsung dibuang.

\subsubsection{Hasil Survey Indikator Penilaian Kualitas Minyak}

Berdasarkan indikator penilaian kualitas minyak, indikator tertinggi ada pada warna yaitu sebesar $45 \%$. Selain warna, indikator penilaian selanjutnya adalah bau dan harga masing-masing sebesar 22\% dan $11 \%$ untuk indikator penilaian lain seperti kejernihan, tidak cepat kotor serta kualitas panasnya baik seperti pada Gambar 6. Masyarakat berpersepsi bahwa warna minyak goreng yang digunakan akan mempengaruhi warna makanan yang dihasilkan sehingga dapat menarik konsumen untuk membeli.

\subsubsection{Hasil Survey Tempat Pembuangan Minyak Goreng}

Berdasarkan tempat pembuangan minyak goreng, tempat sampah merupakan tempat pembuangan terbesar yaitu $67 \%$. Selanjutnya, 22\% penjaja makanan memilih botol untuk menyimpan minyak goreng bekas pakai untuk kemudian dijual kembali dan $11 \%$ membuang minyak goreng bekas pakai ke dalam wastafel seperti Gambar 7. Setelah digunakan minyak goreng dimasukkan ke dalam plastik kemudian dibuang ke tempat sampah, ada juga yang menyimpannya di botol untuk dijual kembali, dan sebagian kecil membuang minyak goreng ke dalam wastafel.

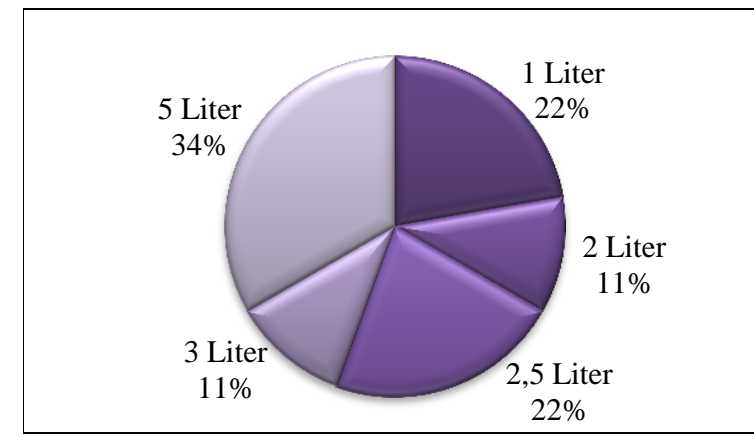

Gambar 4. Persentase Volume Penggunaan Minyak Goreng per hari

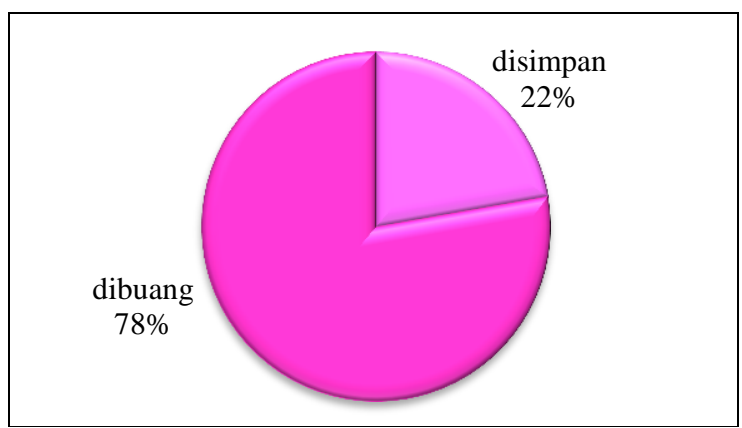

Gambar 5. Grafik Persentase Perlakuan Minyak Goreng Setelah Digunakan

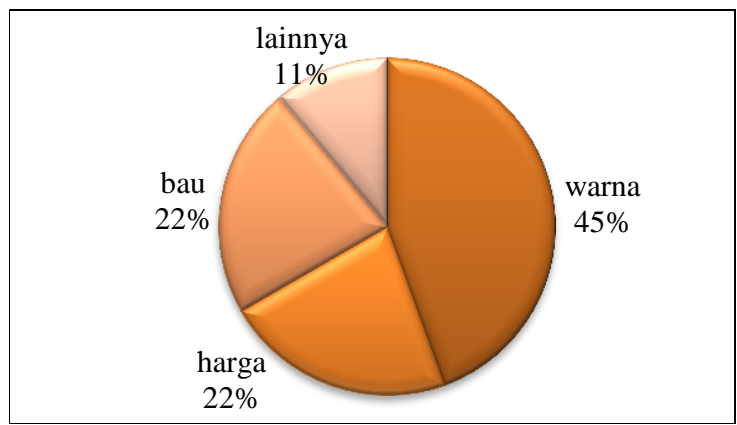

Gambar 6. Grafik Persentase Indikator Penilaian Kualitas Minyak Goreng

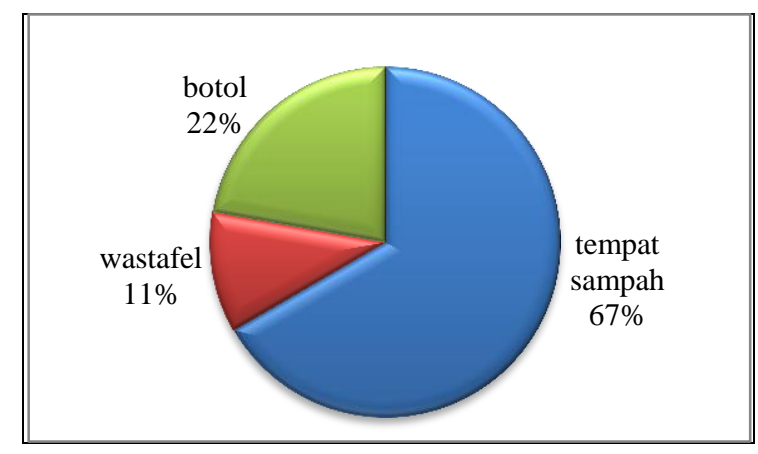

Gambar 7. Persentase Tempat Pembuangan Minyak Goreng 


\subsection{Hasil Analisis Syarat Mutu Minyak Goreng}

Hasil analisis sampel minyak goreng yang diperoleh dari tiga kantin kemudian dianalisis kadar air, asam lemak bebas (asam palmitat) dan bilangan iod (Tabel 3, 4 dan 5). Berdasarkan hasil perhitungan kadar air didapatkan data sebagai berikut:

Tabel 3. Hasil Perhitungan Kadar Air

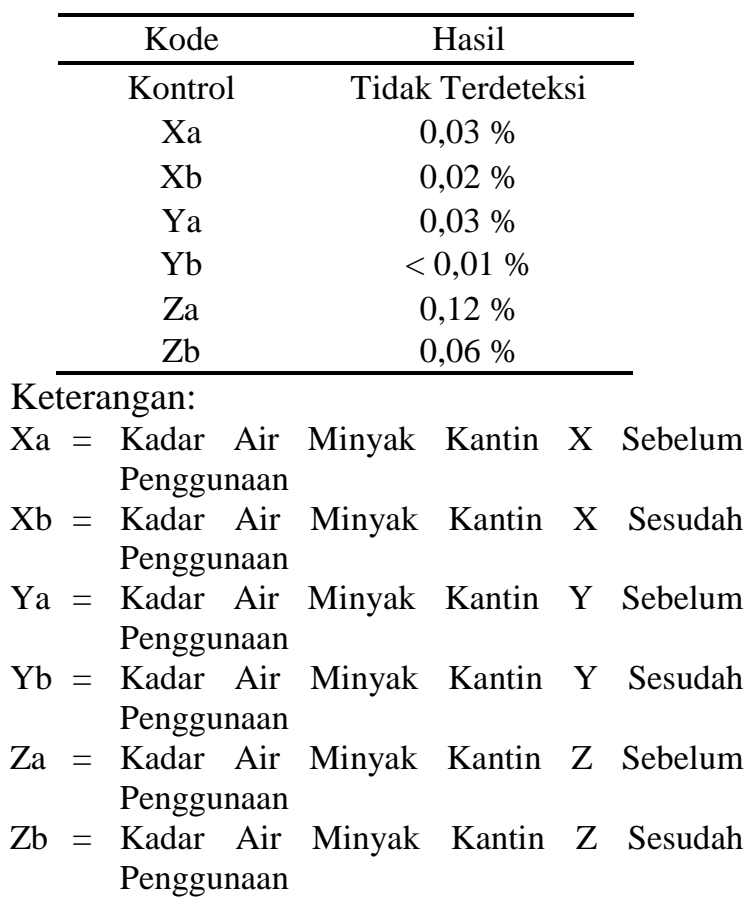

Kadar air sangat penting dalam menentukan daya awet dari bahan makanan karena mempengaruhi sifat fisik, kimia, perubahan mikrobiologi, dan perubahan enzimatis. Kandungan air dalam bahan makanan ikut menentukan penerimaan konsumen, kesegaran, dan daya tahan bahan. Kandungan air yang tinggi dalam bahan menyebabkan daya tahan bahan rendah. Untuk memperpanjang daya tahan suatu bahan, sebagian air dalam bahan harus dihilangkan dengan berbagai cara tergantung dari jenis bahan. Minyak goreng juga mudah terkontaminasi oleh udara dan air (teroksidasi) yang menimbulkan ketengikkan sehingga mempengaruhi cita rasa, daya simpan minyak goreng tersebut menjadi lebih singkat [12].

Berdasarkan Tabel 2, kadar air maksimum yang diperbolehkan terkandung oleh minyak goreng adalah $0,30 \%$. Hal ini sesuai dengan hasil perhitungan kadar air yang didapatkan pada Tabel 3. Pada kontrol minyak, tidak terdeteksi adanya air di dalamnya. Pada sampel minyak sebelum penggunaan dari kantin $\mathrm{x}$ didapatkan kadar air sebanyak $0,03 \%$, kemudian menurun pada sampel minyak sesudah penggunaan yaitu menjadi $0,02 \%$. Pada sampel minyak sebelum penggunaan dari kantin y didapatkan kadar air sebanyak 0,03\%, kemudian menurun pada sampel minyak sesudah penggunaan yaitu menjadi kurang dari $0,01 \%$. Pada sampel minyak sebelum penggunaan dari kantin $\mathrm{z}$ didapatkan kadar air sebanyak $0,12 \%$ kemudian menurun pada sampel minyak sesudah penggunaan yaitu menjadi $0,06 \%$. Penurunan kadar air ini terjadi akibat adanya pemanasan. Hal ini dikarenakan saat pemanasan berlangsung, teradi proses penguapan dengan laju yang berbeda-beda.

Berbeda dengan kadar air, komposisi asam lemak minyak sawit tergantung pada varietas, daerah asal, umur buah maupun posisi buah pada tandan. Selain dipengaruhi oleh faktor-faktor di atas, penanganan pada saat pasca panen dan proses pengolahan juga mempengaruhi komposisi minyak sawit. Sedangkan untuk minyak goreng, komposisi asam lemaknya didominasi oleh asam lemak tidak jenuh karena minyak goreng merupakan produk minyak sawit yang sudah dipisahkan asam lemak jenuhnya dan dikenal sebagai olein.

Salah satu parameter penting yang sering digunakan untuk keperluan analisis praktis adalah bilangan asam. Bilangan asam merupakan indikator kandungan asam lemak bebas dalam minyak dan menjadi pengukur kualitas minyak. Bilangan asam tinggi menunjukkan kualitas minyak yang rendah. Hasil perhitungan kadar asam lemak bebas (Tabel 4).

Tabel 4. Hasil Perhitungan Kadar Asam Lemak Bebas

\begin{tabular}{cc}
\hline Kode & Hasil \\
\hline Kontrol & $0,38 \%$ \\
$\mathrm{Xa}$ & $2,98 \%$ \\
$\mathrm{Xb}$ & $12,07 \%$ \\
$\mathrm{Ya}$ & $3,93 \%$ \\
$\mathrm{Yb}$ & $11,61 \%$ \\
$\mathrm{Za}$ & $5,28 \%$ \\
$\mathrm{Zb}$ & $6,52 \%$ \\
\hline
\end{tabular}

Keterangan:

$\mathrm{Xa}=$ Kadar Asam Lemak Bebas Minyak Kantin $X$ Sebelum Penggunaan

$\mathrm{Xb}=$ Kadar Asam Lemak Bebas Minyak Kantin $X$ Sesudah Penggunaan

$\mathrm{Ya}=$ Kadar Asam Lemak Bebas Minyak Kantin Y Sebelum Penggunaan

$\mathrm{Yb}=$ Kadar Asam Lemak Bebas Minyak Kantin Y Sesudah Penggunaan 


\section{$\mathrm{Za}=$ Kadar Asam Lemak Bebas Minyak Kantin Z Sebelum Penggunaan \\ $\mathrm{Zb}=$ Kadar Asam Lemak Bebas Minyak Kantin Z Sesudah Penggunaan}

Berdasarkan Tabel 2, kadar asam lemak bebas maksimum yang diperbolehkan terkandung oleh minyak goreng adalah 0,30\%. Namun, hasil perhitungan kadar asam lemak bebas pada Tabel 4 menunjukkan perbedaan yang sangat signifikan. Kadar asam lemak bebas yang terdapat pada kontrol minyak adalah $0,38 \%$. Kadar asam lemak bebas yang dimiliki oleh kontrol minyak masih dapat ditolerir, karena selisih kadar asam lemak bebas yang terdapat pada kontrol minyak dengan standard hanya $0,05 \%$. Sedangkan pada sampel minyak sebelum penggunaan dari kantin $\mathrm{X}$ didapatkan kadar asam lemak bebas sebanyak $2,98 \%$, kemudian meningkat pada sampel minyak sesudah penggunaan yaitu menjadi $12,07 \%$. Kemudian pada sampel minyak sebelum penggunaan dari kantin y didapatkan kadar asam lemak bebas sebanyak 3,93\%, kemudian meningkat pada sampel minyak sesudah penggunaan yaitu menjadi $11,61 \%$. Selanjutnya pada sampel minyak sebelum penggunaan dari kantin $\mathrm{z}$ didapatkan kadar asam lemak bebas sebanyak 5,28\% kemudian meningkat pada sampel minyak sesudah penggunaan yaitu menjadi $6,52 \%$.

Kadar asam lemak bebas yang terkandung pada sampel minyak dari kantin $\mathrm{x}$, $\mathrm{y}$ dan $\mathrm{z}$ baik sebelum maupun sesudah penggunaan sangat tinggi dan melebihi ambang batas normal. Bilangan asam yang tinggi menunjukkan kualitas minyak yang rendah. Hal ini didasarkan pada kandungan asam lemak bebas (asam palmitat) dalam minyak. Asam palmitat merupakan golongan asam lemak jenuh. Asam lemak jenuh sendiri merupakan rangkaian poligliserol yang terangkai dan hanya memili ikatan tunggal dan panjang [11]. Inilah yang mengapa menjadi penyebab adanya tingkat kejenuhan pada asam lemak jenuh. Apabila kadar tersebut asam lemak jenuh terlalu berlebihan, akan terjadi pengendapan dalam darah dan tubuh manusia yang akan menyebabkan obesitas hingga penyakit jantung.

Parameter penting lainnya adalah bilangan iodine. Bilangan iodine berhubungan dengan persentase ketidakjenuhan rantai karbon pada asam lemak. Bilangan penyabunan dan bilangan iodine minyak sawit berturut-turut berada kisaran 190-209 dan 5055 [6]. Oleh karena komposisi asam lemak pada minyak goreng didominasi oleh asam lemak tidak jenuh maka bilangan iodine minyak goreng lebih tinggi dibanding minyak sawit. Berdasarkan hasil perhitungan kadar asam bilangan iod, didapatkan data sebagai berikut:

Tabel 5 Hasil Perhitungan Bilangan Iod

\begin{tabular}{|c|c|c|c|c|}
\hline & Kode & Hasil (mg/gr) & & \\
\hline & Kontrol & 71,09 & & \\
\hline & $\mathrm{Xa}$ & 64,45 & & \\
\hline & $\mathrm{Xb}$ & 59,31 & & \\
\hline & $\mathrm{Ya}$ & 56,33 & & \\
\hline & $\mathrm{Yb}$ & 47,97 & & \\
\hline & $\mathrm{Za}$ & 64,45 & & \\
\hline & $\mathrm{Zb}$ & 60,24 & & \\
\hline \multicolumn{5}{|c|}{ Keterangan: } \\
\hline $\mathrm{Xa}$ & $\begin{aligned}= & \text { Bilangan Iod } \\
& \text { Penggunaan }\end{aligned}$ & Minyak Kantin & $\mathrm{X}$ & Sebelum \\
\hline $\mathrm{Xb}$ & $\begin{aligned}= & \text { Bilangan Iod } \\
& \text { Penggunaan }\end{aligned}$ & Minyak Kantin & $\mathrm{X}$ & Sebelum \\
\hline $\mathrm{Ya}$ & $\begin{aligned}= & \text { Bilangan Iod } \\
& \text { Penggunaan }\end{aligned}$ & Minyak Kantin & $\mathrm{Y}$ & Sebelum \\
\hline $\mathrm{Yb}$ & $\begin{aligned}= & \text { Bilangan Iod } \\
& \text { Penggunaan }\end{aligned}$ & Minyak Kantin & $\mathrm{Y}$ & Sebelum \\
\hline $\mathrm{Za}$ & $\begin{aligned}= & \text { Bilangan Iod } \\
& \text { Penggunaan }\end{aligned}$ & Minyak Kantin & $\mathrm{Z}$ & Sebelum \\
\hline $\mathrm{Zb}$ & $\begin{aligned}= & \text { Bilangan Iod } \\
& \text { Penggunaan }\end{aligned}$ & Minyak Kantin & $\mathrm{Z}$ & Sebelum \\
\hline
\end{tabular}

Bilangan iodine menunjukkan derajat ketidakjenuhan asam lemak penyusun minyak. Asam lemak tidak jenuh mampu mengikat iodium dan membentuk persenyawaan yang jenuh. Banyaknya iodine yang diikat menunjukkan banyaknya ikatan rangkap dimana asam lemak tidak jenuh mampu mengikat iodium dan membentuk persenyawaan yang jenuh.

Bilangan iodine juga menyatakan jumlah gram iodine yang diserap dalam satu gram minyak. Berdasarkan Tabel 5 terlihat variasi bilangan iod pada sampel minyak sebelum dipanaskan yaitu berkisar antara 56,33-71,09 mg/gr. Selain itu terlihat adanya penurunan bilangan iod pada sampel minyak yang sudah dipanaskan. Hal ini dapat terjadi karena asam lemak tidak jenuh yang memiliki ikatan kimia serta tidak sekuat dan sekompleks asam lemak jenuh terlisis pada saat pemanasan, sehingga menurunkan bilangan iodine. 


\section{KESIMPULAN}

Analisis penggunaan minyak goreng yang diakukan berdasarkan survey menunjukkan bahwa mayoritas penjaja makanan menggunakan minyak goreng bermerek dagang A sebanyak dua kali pakai dengan pembelian per hari sebanyak $5 \mathrm{~L}$, kemudian minyak tersebut dibuang ke tempat sampah. Analisis syarat mutu melalui analisis kadar air, asam lemak bebas dan bilangan iod menunjukkan bahwa penggunaan minyak goreng pada penjaja makanan di food court UAI belum memenuhi standar syarat mutu, walaupun hasil perhitungan kadar air yang didapatkan masih di dalam ambang batas normal yaitu kurang dari 0,30\%, namun kadar asam lemak yang terkandung pada sampel minyak ketiga kantin yang dijadikan sampel, baik sebelum maupun sesudah penggunaan melebihi ambang batas normal yaitu $0,30 \%$.

\section{UCAPAN TERIMA KASIH}

Terimakasih yang sebesar-besarnya kami sampaikan kepada Lembaga Penelitian dan Pengabdian masyarakat (LP2M), Universitas Al Azhar Indonesia yang telah memberikan kesempatan dan dana sehingga penelitian ini dapat diselesaikan. Terimakasih juga kami sampaikan kepada segenap mahasiswa yang telah membantu penelitian ini.

\section{DAFTAR PUSTAKA}

[1] Bangun, D, Memoar "Duta Besar" Sawit Indonesia, Jakarta: Penerbit Buku Kompas, 2010.

[2] Sitepoe M. 2008. Corat-Coret Anak Desa Berprofesi Ganda, CetakanPertama, Jakarta: Kepustakaan Populer Gramedia, p.15-18, 2008.

[3] Tim Penyusun Kamus Besar Bahasa Indonesia, Kamus Besar Bahasa Indonesia, Balai Pustaka, Jakarta, 1991

[4] Haryono et al, Pengolahan Minyak Kelapa Sawit Bekas Menjadi Biodiesel Studi Kasus: Minyak Goreng Bekas dari KFC Dago Bandung,Pengembangan Teknologi Kimia untuk Pengolahan Sumber Daya Alam Indonesia, Prosiding Seminar Nasional Teknik Kimia "Kejuangan": Yogyakarta, 26 Jan 2010.

[5] Majalah Sasaran No.4 Tahun 2006.

[6] Ketaren, S. 1986. Minyak dan Lemak Pangan, Penerbit Universitas Indonesia (UI Press), Jakarta.1986.

[7] Retno, G, Radikal bebas-sifat dan peran dalam menimbulkan kerusakan-kematian sel, Cermin Dunia Kedokteran 102, 1995.

[8] Chen, S. S., C. C., Cheng, S. S. Chouu., Determination of Arsenic in Edible Oils by Direct Graphite Furnace Atomic Absorption Spectrometry. Journal of Food and Drugs, Vol.11. No. 3 p.214-219, 2003.

[9] Departemen Perindustrian Republik Indonesia (SNI 013741 1995)

[10] Sudarmaji, S et al, Prosedur Analisa untuk Bahan Makanan dan PertanianLibery Press, Yogyakarta, 1976.

[11] Fessenden, R.A., Fessenden, J.S., Kimia Organik Jilid 1, Erlangga, Jakarta, 1992.

[12] Winarno, F.G., Kimia Pangan dan Gizi, Gramedia Pustaka Utama, Jakarta, 1997.

Basiron, Y. B. S., Jalani, and C. K, Weng, Advances in Oil Palm Research. Volume II. Malaysian Palm Oil Board: 1043, 2000 